\title{
Decomposition of Norway spruce and European larch coarse woody debris (CWD) in relation to different elevation and exposure in an Alpine setting
}

\author{
Marta Petrillo ${ }^{(1-2)}$, Paolo \\ Cherubini $^{(2)}$, Giacomo Sartori ${ }^{(3)}$, \\ Samuel Abiven ${ }^{(1)}$, Judith \\ Ascher ${ }^{(4-5)}$, Daniela Bertoldi ${ }^{(6)}$, \\ Federica Camin ${ }^{(6)}$, Alice \\ Barbero $^{(6)}$, Roberto Larcher ${ }^{(6)}$, \\ Markus Egli ${ }^{(1)}$
}

To describe the decay stage of coarse woody debris (CWD) a five decay-class system has been introduced and it is currently the most commonly applied. This system is based on visual, geometric and tactile features of the wood in the field; however, a detailed chemical characterization is often missing. Furthermore, the driving mechanisms (particularly substrate quality vs. environmental conditions) of deadwood decay are controversially discussed. Consequently, we investigated how typical major and minor chemical parameters of wood were correlated with the decay stage. The decomposition patterns of Norway spruce (Picea abies (L.) Karst) and European larch (Larix decidua Mill.) CWD of an Alpine setting were analyzed, and how the chemical and physical parameters were affected by the substrate and environmental conditions was checked. Two altitudinal sequences, having a different exposure (northvs. south-facing sites), were sampled. We measured main biochemical compounds (lignin and cellulose), physical properties (density and water content), element concentrations ( $\mathrm{C}, \mathrm{N}, \mathrm{P}, \mathrm{K}, \mathrm{Ca}, \mathrm{Mg}, \mathrm{Fe}, \mathrm{Mn}$ ), and the carbon isotopic signature $\left(\delta^{13} \mathrm{C}\right)$ of living trees and CWD at five decomposition stages (decay classes). Most investigated wood physico-chemical parameters such as wood density, water content, lignin and cellulose and even minor constituents $(\mathrm{N}$, $\mathrm{Ca}, \mathrm{Mg}, \mathrm{P}, \mathrm{Fe}, \mathrm{Mn}$ ) correlated well to the five decay-class system. Some important components, such as the carbon concentration and $\delta^{13} \mathrm{C}$, did not vary with increasing decomposition. Our hypothesis that the different substrate should be traceable during CWD decay had to be rejected, although some statistically significant chemical differences between larch and spruce were measured in the living trees. The chosen tree species were probably not different enough to be chemically traceable in the CWD. Already in decay class 1 , these differences were zeroed. The site conditions (expressed by the different altitudes and exposure) influenced only some of the investigated parameters, namely lignin, the $\delta^{13} \mathrm{C}$ isotopic ratio and nutrients such as $\mathrm{P}, \mathrm{Ca}$ and $\mathrm{K}$.

Keywords: Deadwood, Alps, Norway Spruce, European Larch, Decomposition, Lignin, Nutrients, Carbon Isotopes

al. 2007, Rondeux \& Sanchez 2010). Deadwood also plays an important role in $C$ and nutrient dynamics (Laiho \& Prescott 2004). Large-dimension residues, though not uni-

\section{Introduction}

Deadwood has a well-acknowledged role in forest functioning: it is a habitat for ma ny autotrophs and heterotrophs (Zhou et versally defined, are referred to as coarse woody debris (CWD), i.e., logs, snags and coarse roots. In natural forests, the CWD input results from tree mortality. In managed forests, CWD is also influenced by logging activities and management practices (e.g., left-over stumps and branches). In both natural and managed systems, the input rate is also dependent on the occurrence of major disturbances, such as wind storms or pathologic dieback that can occasionally introduce further amounts of deadwood (Bütler et al. 2007, Harmon et al. 2013).

Depending on the forest ecosystem, CWD can greatly vary, accounting for 10 to more than $30 \%$ of the aboveground biomass of forests (Brown 2002, Bobiec 2002, Bobiec et al. 2005). On a global level, it represents $8 \%$ of the forests' C stock (Pan et al. 2011). For North America and Europe, an increase in woody biomass (Risch et al. 2013) coupled with an increased environmental disturbance regime (Seidl et al. 2014) may 
lead to a larger amount of CWD in the short-term. However, a decrease in CWD could be expected as a response to climate warming, due to enhanced decomposition rates (Kueppers et al. 2004).

Decay mechanisms of CWD are driven by physical, chemical and biological processes (Harmon et al. 1986). However, it is often difficult to differentiate between the factors controlling the decay mechanisms (Cornelissen et al. 2012, Risch et al. 2013, Harmon et al. 2013). Furthermore, due to the highly heterogeneous spatial distribution and its long-term decay dynamics, CWD is less represented in decomposition studies. Therefore, it is not surprising that the discussion about the driving factors is still controversial and consequently a matter of debate. While some authors point to the importance of substrate quality, others emphasize the role of climatic conditions.

Decomposition of CWD is largely driven by microbial (mainly fungal) activity, which is influenced by substrate quality and environmental conditions (Harmon et al. 1986). Disentangling the role of the different decomposition drivers is challenging because of their strong interactions (Cornelissen et al. 2012). Lignin, cellulose and nitrogen (N) interactions seem to exert a major control on litter decomposition (Talbot \& Treseder 2012). Micronutrients can also be important for decomposition, but are less reported in literature. For example, in the late decomposition stage, manganese $(\mathrm{Mn})$ seems to be essential for lignin degradation (Berg et al. 2013). However, in the Austrian Alps Djukic et al. (2013) found that environmental conditions rather than substrate determine the decomposer community. Temperature and water content explained $74 \%$ of the variation in CWD respiration in an incubation experiment of boreal black spruce (Wang et al. 2002). Risch et al. (2013) found that soil temperature was the best explanatory variable for the decomposition rate of wood stakes in the Swiss Alps.

The general problem of precise determination of the CWD decay processes seems to be even more basic. To get an overview of CWD and decay mechanisms on a wider area (and not just on a lab or a plot scale), relatively simple tools are required to characterize and quantify the processes. In the field, the different steps of CWD decomposition are often described by so-called decay classes that are determined by visual assessment of the wood (Lombardi et al. 2013). The five decay-class system is the one most commonly applied (Bütler et al. 2007, Harmon et al. 2013, Lombardi et al. 2013 - see Tab. 1). Some authors have tested the effectiveness of using a different number of classes (Teodosiu \& Bouriaud 2012). Unfortunately, a detailed chemical characterization of such decay classes is often missing for specific tree species and is based on purely macromorphological observations. As suggested by several authors (Ganjegunte et al. 2004, Bütler et al. 2007, Saunders et al. 2011, Lombardi et al. 2013), wood density, carbon, nitrogen and phosphorous contents together with lignin and cellulose concentrations may be used to better assess the decay patterns of CWD in relation to specific site conditions (Rock et al. 2008).

In this study we focused on typical major and minor wood chemical parameters in order to understand how they correlate with the decay stage. The decomposition patterns of Norway spruce (Picea abies (L.) Karst) and European larch (Larix decidua Mill.) CWD of an Alpine setting were analyzed. Furthermore, we tried to trace back how decay stages and chemical parameters were affected by site conditions (different elevations and exposure). Our starting hypothesis was that the physical and chemical properties of CWD would be different for spruce and larch; consequently, differences in the substrate are expected to be traceable also during CWD decomposition. Moreover, we hypothesized that CWD quality would vary with elevation and exposure, since climatic conditions not only affect the rate of CWD decomposition, but also the chemical composition of the remaining CWD. We assumed that more favorable climatic conditions enhanced the decomposition occurring at the south-facing and low-elevation sites of the chosen area. As a consequence, a greater loss of cellulose and a stronger increase in nitrogen and phosphorus, along with a higher (less negative) $\delta^{13} \mathrm{C}$, are expected at southfacing sites, due to the enhanced growth of fungal mycelia within the wood.

\section{Materials and methods}

\section{Study area, investigation sites and} experimental setup

The investigation area was located in Val di Sole and Val di Rabbi, Trentino, in the south Alpine belt of northern Italy (Fig. 1). The climate of the valleys ranges from temperate to alpine (above the timberline). Mean annual temperature varies from 8.2 ${ }^{\circ} \mathrm{C}$ in the valley floor to about $0{ }^{\circ} \mathrm{C}$ at 2400 $\mathrm{m}$ a.s.l., and mean annual precipitation approximately from 800 to $1300 \mathrm{~mm}$ (Sboarina \& Cescatti 2004). The geological substrate is paragneiss debris at all the sites. Soil units are Cambisols, Umbrisols and Podzols (WRB, IUSS Working Group 2007 Tab. 1). The timberline is close to $2000-2200$ $\mathrm{m}$ a.s.l. and the forests are dominated by Norway spruce (Picea abies (L.) Karst) and at the highest altitudes by European larch (Larix decidua Mill.).

Eight plots along two altitudinal transects (climosequences) were investigated: one north- and one south-facing. Each climosequence included four sites from 1200 up to $2000 \mathrm{~m}$ a.s.l. (Tab. 2, Fig. 1). Using this approach, a broad temperature range (ap-

Tab. 1 - Characteristics of the study sites. (MAAT): mean annual air temperature; (MAP): mean annual precipitation (Sboarina \& Cescatti 2004); (b): thermal favorable conditions on south-facing sites included (according to Ascher et al. 2012).

\begin{tabular}{|c|c|c|c|c|c|c|c|c|c|c|}
\hline Sites & $\begin{array}{l}\text { Plot } \\
\text { ID }\end{array}$ & 离 & 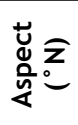 & 은 & 桌它 & 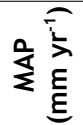 & $\begin{array}{l}\text { Parent } \\
\text { material }\end{array}$ & $\begin{array}{l}\text { Dominating } \\
\text { tree species }\end{array}$ & Land use & $\begin{array}{l}\text { Soil classification } \\
\text { (WRB - Egli et al. 2006) }\end{array}$ \\
\hline \multirow{4}{*}{$\begin{array}{l}\text { North- } \\
\text { facing } \\
\text { sites }\end{array}$} & N01 & 1180 & 340 & 31 & 5.6 & 950 & Paragneiss debris & Picea abies & $\begin{array}{l}\text { Natural forest } \\
\text { (ecological forestry) }\end{array}$ & $\begin{array}{l}\text { Chromi-Episkeletic } \\
\text { Cambisol (Dystric) }\end{array}$ \\
\hline & N02 & 1390 & 0 & 28 & 4.6 & 1000 & Paragneiss debris & Picea abies & $\begin{array}{l}\text { Natural forest } \\
\text { (ecological forestry) }\end{array}$ & $\begin{array}{l}\text { Chromi-Episkeletic } \\
\text { Cambisol (Dystric) }\end{array}$ \\
\hline & N03 & 1620 & 0 & 29 & 3.5 & 1060 & Paragneiss debris & Picea abies & $\begin{array}{l}\text { Natural forest } \\
\text { (ecological forestry) }\end{array}$ & $\begin{array}{l}\text { Chromi-Endoskeletic } \\
\text { Cambisol (Dystric) }\end{array}$ \\
\hline & N04 & 1930 & 20 & 12 & 1.4 & 1180 & $\begin{array}{l}\text { Paragneiss debris, } \\
\text { moraine material }\end{array}$ & Larix decidua & $\begin{array}{l}\text { Originally used } \\
\text { as pasture }\end{array}$ & Episkeletic Podzol \\
\hline \multirow[t]{4}{*}{$\begin{array}{l}\text { South- } \\
\text { facing } \\
\text { sites }\end{array}$} & S06 & 1185 & 160 & 31 & $8.6^{\mathrm{b}}$ & 950 & Paragneiss debris & Picea abies & $\begin{array}{l}\text { Ex-coppice, natural } \\
\text { forest (ecological } \\
\text { forestry) }\end{array}$ & $\begin{array}{l}\text { Episkeleti-Endoleptic } \\
\text { Cambisol (Chromi-Dystric) }\end{array}$ \\
\hline & S07 & 1400 & 145 & 33 & $7.6^{\mathrm{b}}$ & 1000 & Paragneiss debris & Larix decidua & $\begin{array}{l}\text { Natural forest } \\
\text { (ecological forestry) }\end{array}$ & $\begin{array}{l}\text { Dystri-Endoskeletic } \\
\text { Cambisol }\end{array}$ \\
\hline & S08 & 1660 & 210 & 33 & $6.5^{\mathrm{b}}$ & 1060 & Paragneiss debris & Picea abies & $\begin{array}{l}\text { Natural forest } \\
\text { (ecological forestry) }\end{array}$ & Skeletic Umbrisol \\
\hline & S09 & 1995 & 160 & 25 & $4.4^{\mathrm{b}}$ & 1180 & Paragneiss debris & Larix decidua & $\begin{array}{l}\text { Ex pasture, natural } \\
\text { forest }\end{array}$ & Skeletic Umbrisol \\
\hline
\end{tabular}


Fig. 1 - Location of the study area (Val di Sole and Val di Rabbi) with major vegetation units and the investigation sites: north-facing (No1-No2-N03-No4) and south-facing sites (SO1-S02-S03-S04). Data source: Museo delle Scienze (Trento), CORINE Landcover (Joint Research Center of the European Union) and scilands $\mathrm{GmbH}$.

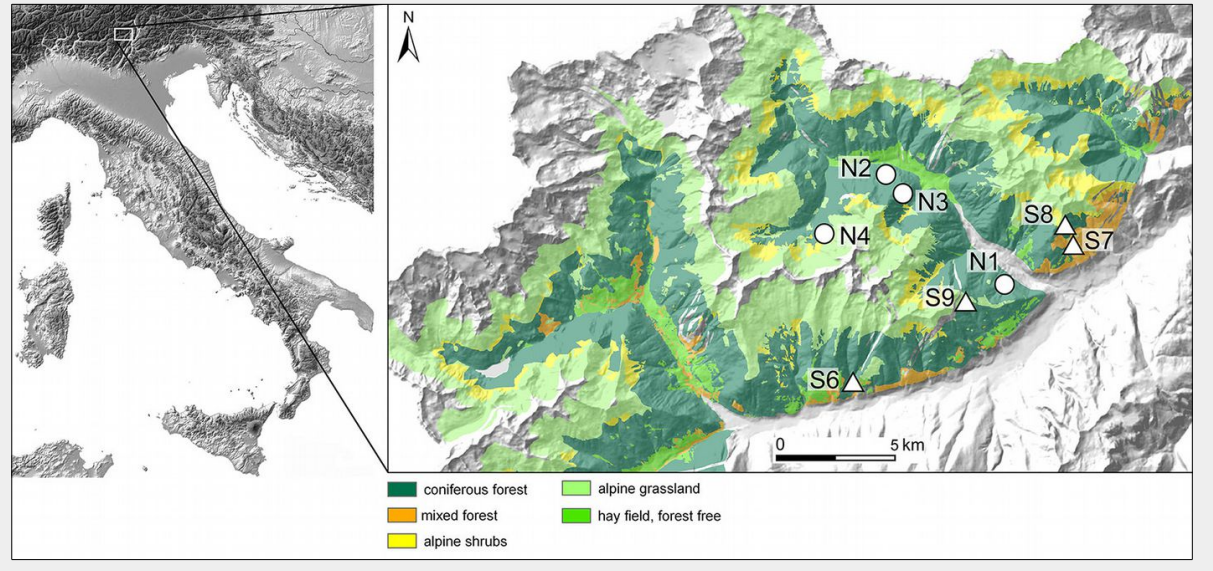

prox. $6.2^{\circ} \mathrm{C}$ differences in mean annual air temperature between coldest and warmest site) was covered having distinctly different thermal conditions. Differences in surface temperature between north- and south-facing sites in the Alpine area are usually between 2 and $3{ }^{\circ} \mathrm{C}$ (Ascher et al. 2012). The following thermal sequence (from warmer to cooler sites) for the chosen sites (Tab. 1) is given: So6 (1200 m a.s.l., south) > So7 (1400 m a.s.l., south) > No1 $(1200 \mathrm{~m}$ a.s.l., north $) \approx \mathrm{S} 08$ (1600 $\mathrm{m}$ a.s.l., south) > No2 (1400 m a.s.l., north) > No3 $(1600 \mathrm{~m}$ a.s.l., north $) \approx \operatorname{Sog}(2000 \mathrm{~m}$ a.s.l., south) > No4 (2000 m a.s.l., north). We investigated natural and typical forest sites for this part of the Alps. The dominant tree and deadwood species is Norway spruce at 1200 and $1600 \mathrm{~m}$ a.s.l., both at the northand south-facing sites (Tab. 2). At $1400 \mathrm{~m}$ a.s.l., Norway spruce is dominant at the north-facing slope, and European larch at the south-facing slope. At $2000 \mathrm{~m}$ a.s.l. the dominant species is European larch.

\section{CWD volume assessment within the} plots

At each plot, a fixed square area of $25 \times$ $25 \mathrm{~m}$ was delimited. Within this area, all CWD having a minimum diameter of $5 \mathrm{~cm}$ and a length of $\geq 100 \mathrm{~cm}$ was measured (length, maximum diameter and minimum diameter). Furthermore, the decay class was registered for the CWD. We classified CWD of Norway spruce and European larch using the five decay-class system (Hunter 1990). This system is based on visual, geometric and tactile features (Tab. 2). The CWD volume was calculated using the geometric formula of the circular truncated cone (eqn. 1):

$$
V=\frac{1}{3} \pi\left(r_{1}^{2}+r_{1} \cdot r_{2}+r_{2}^{2}\right) \cdot h
$$

where $V$ is the volume, $h$ is the length of the CWD and $r_{1}$ and $r_{2}$ are the upper and lower radius, respectively.

When standing dead trees were present, they were also recorded and measured (height and diameter at $1.30 \mathrm{~m}$ above the ground). The volume of standing dead trees was estimated using the double-entry volume tables specific for Norway spruce and European larch of this region (Castellani 1972). The total volume of deadwood within the fixed area was referred to one hectare. The CWD carbon stocks ( $M g$ ha ${ }^{-1}$ ) were calculated for every single site using the eqn. 2 :

$$
C_{\text {stock }}=\sum_{i} \frac{V_{i} \cdot C C_{i} \cdot \rho_{i}}{100}
$$

where $i$ is the decay class, $V$ is the volume $\left(\mathrm{m}^{3} \mathrm{ha}^{-1}\right)$ referred to one hectare, $C C$ is the carbon concentration (\%) and $\rho$ is the density $\left(\mathrm{g} \mathrm{cm}^{-3}\right)$. For the conversion of deadwood volume into $C$ stocks, average values of density and $C$ concentrations for each single decay class were used.

\section{Sample collection and preparation}

At all sites, we selected circular areas having a radius of about $50 \mathrm{~m}$. Such extension (compared to the CWD assessment) was chosen in order to obtain enough replicates for each decay class. Each log was assigned to a single decay class (Hunter 1990). In a few cases (less than $5 \%$ of the total sampled logs) a log could be assigned to more than one decay class. In these cases, samples were then taken from the portion where a clear assignment to a

single prevalent decay class was possible. At least 3 samples of each decay class were taken at all sites. When this minimum number was not reached within the sampling area, we explored the adjacent surroundings until the minimum sample number was reached. Samples were taken randomly and using a manual saw or, in more advanced stage of decay, simply by hands. For CWD in decay classes 1, 2 and 3, crosssections of 5-10 cm thickness were taken. For the more advanced decay stages, a $25 \times$ $30 \mathrm{~cm}$ bag was filled. The same number of replicates could not always be collected for each decay class at each site because of the different amount and accessibility of deadwood. Overall, 177 samples were analyzed. Focus was given on Norway spruce samples (because this species is dominant in the region). At the highest sites, the forest is dominated by European larch, whose CWD was sampled here, while Norway spruce was almost absent and no samples could be taken. At all other sites only Norway spruce samples were taken. At the south-facing site at $1400 \mathrm{~m}$ a.s.l., predominantly European larch was found (together with Norway spruce). To enable a better comparison between north- and south-facing sites, Norway spruce samples were taken at this site.

\begin{tabular}{|c|c|c|c|c|c|}
\hline \multirow{2}{*}{$\begin{array}{l}\text { Log } \\
\text { features }\end{array}$} & \multicolumn{5}{|c|}{ Decay classes } \\
\hline & 1 & 2 & 3 & 4 & 5 \\
\hline Bark & Intact & $\begin{array}{l}\text { Partially } \\
\text { absent }\end{array}$ & Absent & Absent & Absent \\
\hline Twigs & Present & $\begin{array}{l}\text { Partially } \\
\text { absent or } \\
\text { absent }\end{array}$ & Absent & Absent & Absent \\
\hline $\begin{array}{l}\text { Shape of } \\
\text { radial section }\end{array}$ & Round & Round & Round & Oval & Very oval \\
\hline Colour & Original & Original & $\begin{array}{l}\text { Faded in the } \\
\text { external part }\end{array}$ & $\begin{array}{l}\text { Reddish } \\
\text { brown or } \\
\text { faded }\end{array}$ & $\begin{array}{l}\text { Reddish or } \\
\text { faded }\end{array}$ \\
\hline $\begin{array}{l}\text { Texture of } \\
\text { wood }\end{array}$ & Intact & Intact & $\begin{array}{l}\text { Soft outer } \\
\text { layer, intact } \\
\text { inner part }\end{array}$ & $\begin{array}{l}\text { Small pieces, } \\
\text { soft }\end{array}$ & $\begin{array}{l}\text { Powdery or } \\
\text { fibrous, very } \\
\text { soft }\end{array}$ \\
\hline $\begin{array}{l}\text { Contact with } \\
\text { soil }\end{array}$ & $\begin{array}{l}\text { Log elevated } \\
\text { on what } \\
\text { remains of } \\
\text { branches }\end{array}$ & $\begin{array}{l}\text { Log in contact } \\
\text { with soil }\end{array}$ & $\begin{array}{l}\text { Log in contact } \\
\text { with soil }\end{array}$ & $\begin{array}{l}\text { Log in contact } \\
\text { with soil }\end{array}$ & $\begin{array}{l}\text { Log in contact } \\
\text { with soil and } \\
\text { partially } \\
\text { buried }\end{array}$ \\
\hline
\end{tabular}

Tab. 2 - The five decay-class system of log decomposition (according to Hunter 1990). 
In addition, sample replicates of three different living trees were taken (at a breast height of $1.3 \mathrm{~m}$ ) at each plot using an increment wood corer (Suunto) having a diameter of $5 \mathrm{~mm}$. The trees were cored to the pith from two opposite directions so that two wood cores were obtained from each selected tree. The two cores from the same tree were pooled together.

All samples were weighed and dried in the oven at $50^{\circ} \mathrm{C}$ until a constant weight was attained. For chemical analyses, all samples were milled to a powder $(<60 \mu \mathrm{m})$ using a planetary ball mill. Prior to this operation, mosses and soil particles were removed using a brush. Bark (when present) was also removed in order to avoid an unnecessarily broader variability in chemical composition (Harmon et al. 2013). Sapwood and heartwood were pooled together to avoid differences between classes in which sapwood and heartwood were still distinct and classes in which such a distinction was no longer possible.

\section{Density}

Density was measured in the CWD only and calculated as the ratio between the dry weight at $50{ }^{\circ} \mathrm{C}$ and the fresh volume. The volume of each sample was estimated by water displacement. The samples of the decay classes 3, 4 and 5 were first vacuum sealed in plastic bags to avoid waterabsorption and wood-particle dispersion in water. Vacuum sealing was performed using a food-packaging sealer. To avoid compaction of CWD of classes 4 and 5, sealing was performed using a low energy level. Using plastic-covered samples, the volume may be overestimated when hollows are present (due to e.g., heart-rot fungi). By measuring small fragments (about 6 $\mathrm{cm}^{3}$ ), the volume estimation error is minimized because only micro-pores are present. Furthermore, the volume of the plastic bag alone was subtracted from the sample volume. To estimate the accuracy of the method, standard wood blocks $(5 \times 5 \times$ $2 \mathrm{~cm}$ ) were used to measure water displacement with and without vacuum sealing. The differences between the resulting densities were in the range of $2-5 \%$.

\section{Cellulose and lignin determination}

To obtain a-cellulose (Boettger et al. tute, PSI, Switzerland) using an elemental

Tab. 3 - Comparison of chemical and physical characteristics between Norway spruce and European larch. Mean values ( \pm standard deviation) are given only for parameters showing significant differences between the two species. With respect to CWD, only the density in decay class 1 was found to differ significantly between the two species.

\begin{tabular}{llcrr}
\hline Type & Parameter & Spruce & \multicolumn{1}{c}{ Larch } & P-value \\
\hline Living & Cellulose $(\%)$ & $45.10 \pm 3.90$ & $39.40 \pm 4.80$ & 0.004 \\
trees & Carbon $(\%)$ & $45.20 \pm 0.80$ & $43.50 \pm 1.50$ & 0.004 \\
& $\mathrm{~K}(\mathrm{~g} / \mathrm{kg})$ & $0.51 \pm 0.29$ & $0.20 \pm 0.07$ & $<0.001$ \\
& $\mathrm{Ca}(\mathrm{g} / \mathrm{kg})$ & $1.24 \pm 0.56$ & $0.61 \pm 0.40$ & $<0.001$ \\
& $\mathrm{Fe}(\mathrm{mg} / \mathrm{kg})$ & $33.80 \pm 21.99$ & $11.19 \pm 7.66$ & $<0.001$ \\
& Mn $(\mathrm{mg} / \mathrm{kg})$ & $50.47 \pm 14.22$ & $14.19 \pm 3.77$ & $<0.001$ \\
CWD & Density in decay-class $1\left(\mathrm{~g} \mathrm{~cm}^{-3}\right)$ & $0.44 \pm 0.15$ & $0.59 \pm 0.11$ & 0.027 \\
\hline
\end{tabular}

analyser (EA 1110, Carlo Erba, Thermoquest, Italy) and an isotope-ratio mass spectrometer (Delta S. Thermo Finnigan MAT, Thermo Electron $\mathrm{GmbH}$, Germany). The measured $\delta^{13} \mathrm{C}$ values were $-27.7 \%$ and $-12.72 \%$ for Betula spp. and Miscanthus spp., respectively. The results of the isotope analysis are expressed as a $\delta$ value (\%) relative to the international Pee Dee Belemnite standard as follows (eqn. 3):

$$
\delta^{13} C=\frac{R_{s}-R_{s t}}{R_{s t}} \cdot 1000
$$

where $\delta^{13} \mathrm{C}$ is expressed in permil (\%), $R$ is the ratio ${ }^{13} \mathrm{C} /{ }^{12} \mathrm{C}, S$ is the sample and $S t$ is the standard. Calibration was carried out using the international standards IAEA-USGS24, IAEA-CH-6 and IAEA-CH-7.

\section{Nutrients}

The nutrient contents ( $\mathrm{N}, \mathrm{P}, \mathrm{K}, \mathrm{Ca}, \mathrm{Mg}, \mathrm{Fe}$, $\mathrm{Mn})$ in the CWD and in each single living tree sample were measured. Sub-samples of the CWD samples of the same plot and decay class were pooled ( 5 decay classes $\times$ 8 sites $=40$ samples). The total content of $\mathrm{N}$ was determined using a $\mathrm{CN}$ analyser (Vario Macro CN, Elementar, Hanau, Germany - combustion analysis) and the content of $\mathrm{P}, \mathrm{K}, \mathrm{Ca}$ and $\mathrm{Mg}$ using ICP-OES (Optima 8300, Perkin Elmer, Waltham, USA) after acid digestion of $0.5 \mathrm{~g}$ of powdered wood with $4 \mathrm{ml}$ of $\mathrm{HNO}_{3}$ in a closed vessel (UltraWAVE Milestone, Shelton, CT, USA - max temperature $230^{\circ} \mathrm{C}$ ).

\section{Statistical analysis}

Data were first checked for normal distribution by a Shapiro-Wilk test (SigmaPlot ${ }^{\circledR}$ ver. 11.0, Systat Software Inc. - Jann 2005). CWD data showed significant departure from normality, while for living trees only a part of the data were normally distributed. No normal distribution was achieved even after several types of data transformations (i.e., square, square root, logarithm, BoxCox), therefore the U-test (Mann-Whitney) was used to test for differences between two groups. For data showing a normal distribution, a Student's two-tails $t$-test was applied. The Spearman's rank correlation coefficient was used when the data did not show a normal distribution. To perform multiple comparison tests for non-parametric data, one-way ANOVA (Kruskal-Wallis test) was applied using the package "pgirmess" of the software R. The level of significance was $p<0.05$.

\section{Results}

Effect of different tree species on wood properties of living trees and CWD

The results of the statistical analysis carried out revealed significant differences in several parameters of living trees between Norway spruce and European larch (hereafter referred as spruce and larch). Contrastingly, most variables in CWD did not differ between the two species (Tab. 3). In 
Fig. 2 - Box plots for decay classes 1 to 5 (both tree species, larch and spruce, are treated as one entity; see text for explanation) and living trees (distinction between spruce and larch) with respect to: (A) a-cellulose; (B) Klason lignin; (C) carbon; (D) the isotopic ratio $\delta^{13} \mathrm{C}$. Different letters indicate significant differences among the decay classes tested with multiple comparison tests (nonparametric ANOVA, Kruskal-Wallis) with a significance level at $P<0.05$. For living trees, differences between European larch and Norway spruce are indicated as follows: $(*) P$ $<0.05 ;(* *): P<0.01 ;(* * *)$ : $P<0.001$.
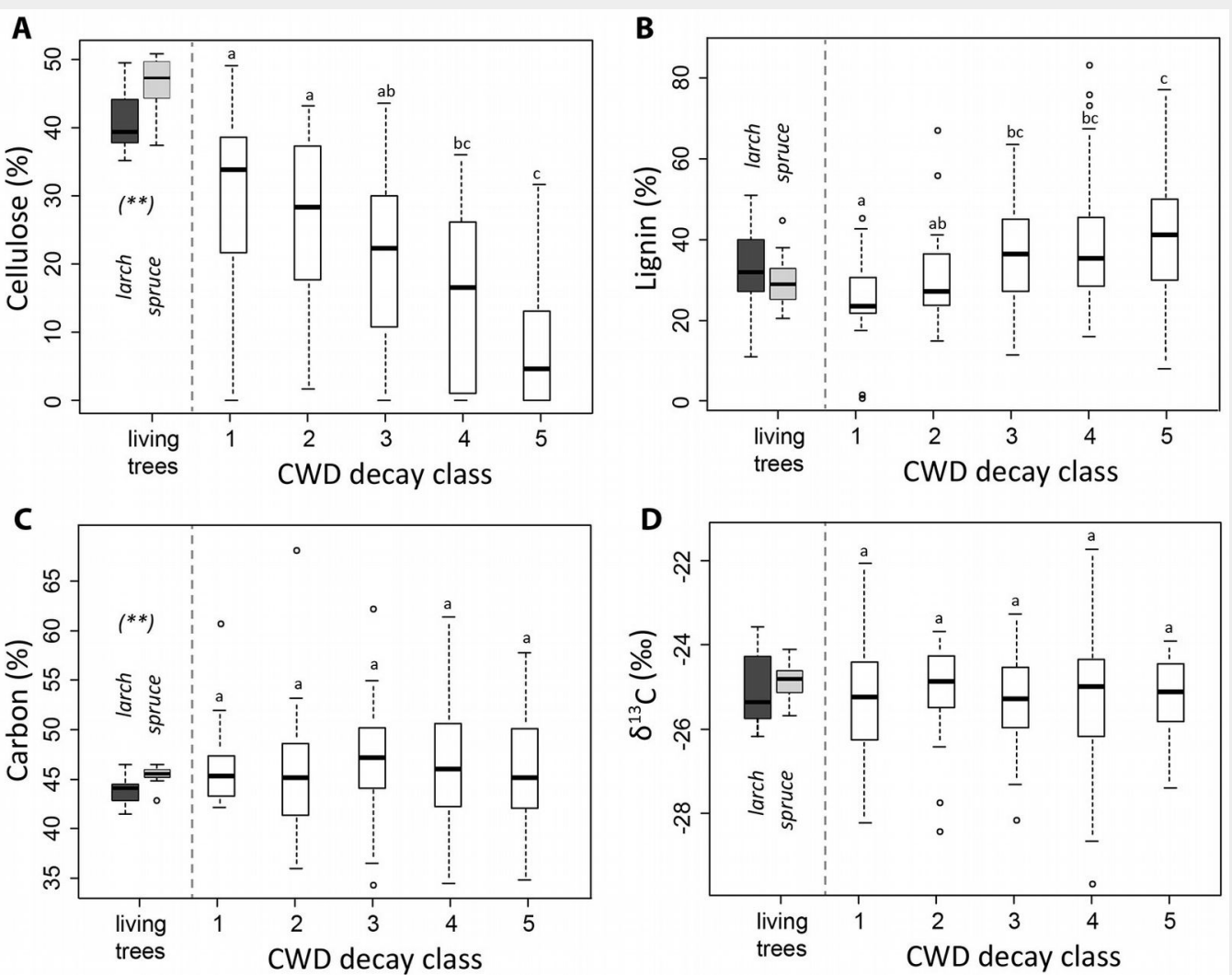

Living trees:

decay class 1 , spruce wood was less dense than larch wood (0.44 vs. $0.59 \mathrm{~g} \mathrm{~cm}^{-3}$, respectively). During the decomposition, however, such difference steadily became smaller, and finally the two species reached the same value in the decay class 5 $\left(0.2 \mathrm{~g} \mathrm{~cm}^{-3}\right)$.

Wood of living spruce trees had significantly more cellulose ( $45 \%$ for spruce vs. $39 \%$ for larch) and slightly less lignin (Fig. $2 \mathrm{~A}$, Fig. $2 \mathrm{~B}$ ) than larch. The difference in lignin content was, however, not significant (27\% in spruce, $29 \%$ in larch). Although very small, some differences in the total carbon content between the two tree species could be measured ( 45.2 vs. $43.5 \%$ for spruce and larch, respectively).

Carbon, nitrogen and phosphorus had similar values for spruce and larch both in the living trees and CWD. As for living trees, Mg, K, Fe and Mn were usually more abundant in spruce than in larch (Fig. 3). However, no differences between larch and spruce could be detected in the CWD with respect to cellulose, lignin and all other major or minor nutrients (Tab. 3). Based on this result, we consider the whole dataset as one entity (spruce and larch) for further statistical analyses.

\section{Physical-chemical properties of CWD during decomposition}

The decay stage was a determining factor for several major compounds (water content, density, cellulose, lignin, nitrogen, phosphorus and iron). For the carbon concentration, $\delta^{13} \mathrm{C}$ and several elements; however, no statistically significant relation to the decay class could be detected. The water content of CWD increased with increasing the decay class, with a particularly significant differences between the decay classes 1-2-3 and 4-5 (Fig. 4A). The wood density exhibited a clearly opposite trend (Fig. 4B). Both cellulose and lignin correlated well with the decay classes. Furthermore, a significant negative correlation between these two components was found ( $\rho=$ $-0.63 ; P<0.05$ - Fig. 5).

With increasing decay stage, the cellulose content decreased steadily $(P<0.001$ - Fig. $2 \mathrm{~A})$. In the last two decomposition stages (decay classes 4 and 5), several samples (33\%) did not contain any cellulose at all. Differences in cellulose content between adjacent decay classes were statistically significant in all cases except for classes 1 and 2 . In contrast to cellulose, the lignin content increased with increasing decay stage (Fig. 2B). The carbon concentration of CWD ( $46 \%$ on average) did not exhibit any significant variations among decay classes (Fig. 2C). A similar pattern was found for the $\delta^{13} \mathrm{C}$ isotopic ratio $(-25.26 \%$ on average), with no significant differences and no evident trend across decay classes (Fig. 2D). Nitrogen and phosphorus concentrations steadily and significantly increased with increasing decay class (Fig. $3 \mathrm{~A}$, Fig. $3 \mathrm{E})$. Iron had a significant $(P=0.03)$ increase in classes 4 and 5 (Fig. 3F), while manganese was most abundant in classes 2, 3 and 4 (Fig. 3G). However, for the other elements ( $\mathrm{Ca}, \mathrm{Mg}, \mathrm{K})$ no distinct trend was found. All element concentrations were significantly higher $(P<0.001)$ in the CWD compared to the living trees (Fig. 3).

\section{Influence of elevation and exposure on} physical-chemical properties of CWD

Compared to the south-facing sites, the average water content of samples seemed to be slightly higher at the north-facing sites in decay class 1 (34 $\pm 14 \%$ vs. $30 \pm 9 \%$, respectively), decay class 4 ( $63 \pm 11 \%$ vs. 59 $\pm 17 \%$, respectively) and decay class 5 (72 \pm $9 \%$ vs. $62 \pm 15 \%$, respectively). However, these differences were statistically significant only in the last case (north vs. south in class $5, P=0.018$ ). If all decay classes are considered together, no significant effect of elevation and exposure on the water content was found (Tab. 4). To a certain degree, density seemed to be influenced by elevation (statistical significant correlation with elevation, $P=0.017$ - Tab. 4). This trend, however, might be slightly biased by the fact that CWD density in decay class 1 is higher in larch than in spruce. Furthermore, the larch samples were from the highest sites. The cellulose concentration in CWD showed significantly higher values in decay classes 1 at north-facing sites compared to south-facing sites (38 vs. $23 \%$, respectively; $P=0.002$ - Fig. 6). With increasing decay 
A

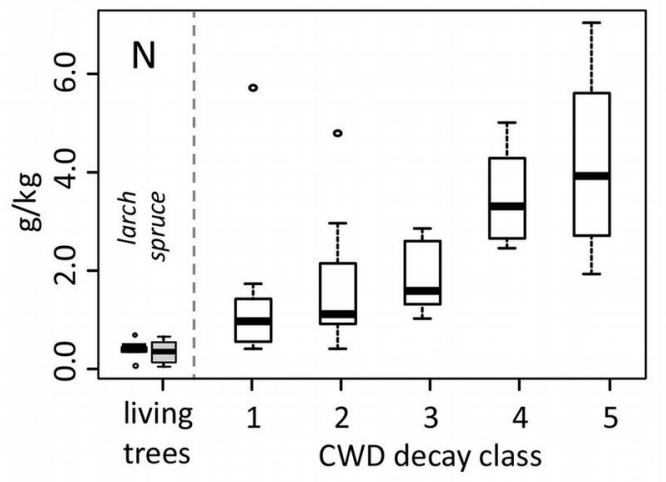

C

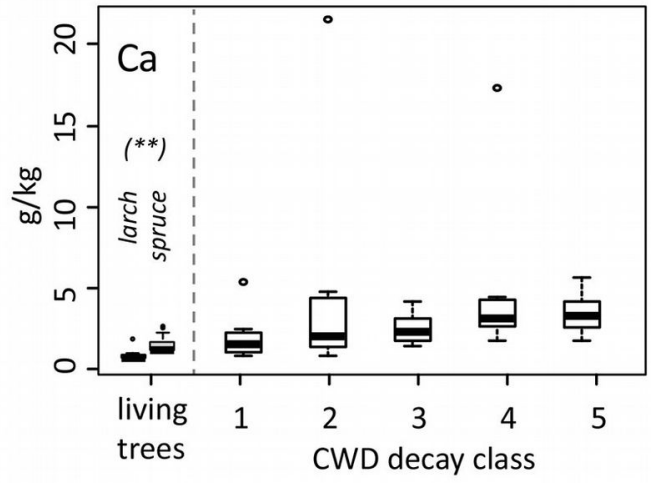

E

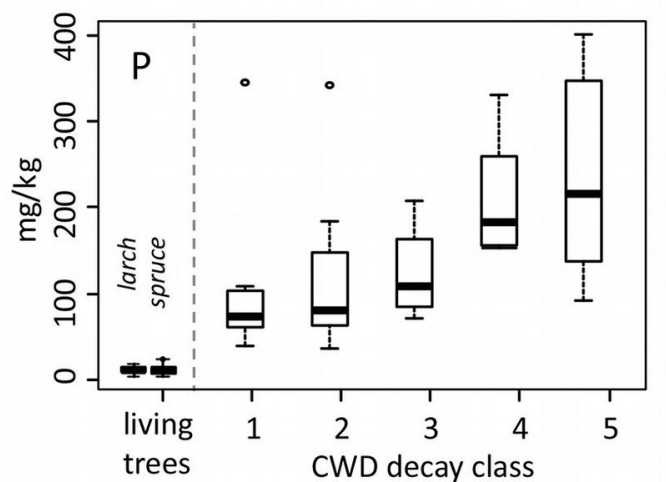

G

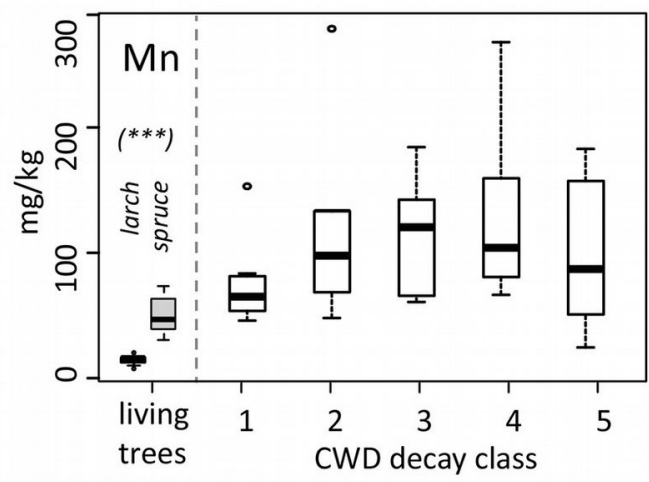

B

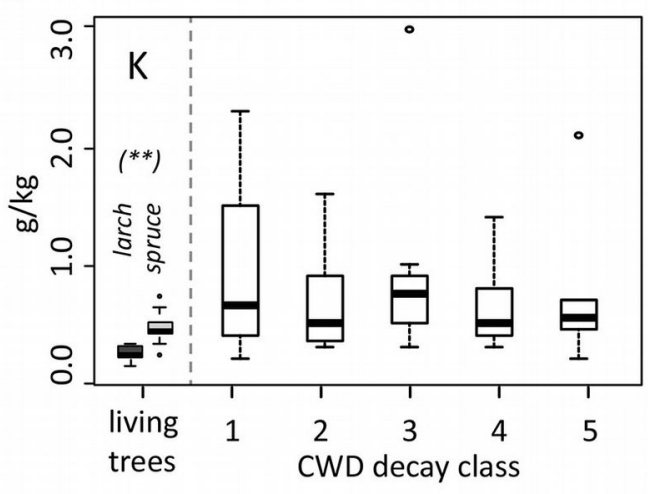

D

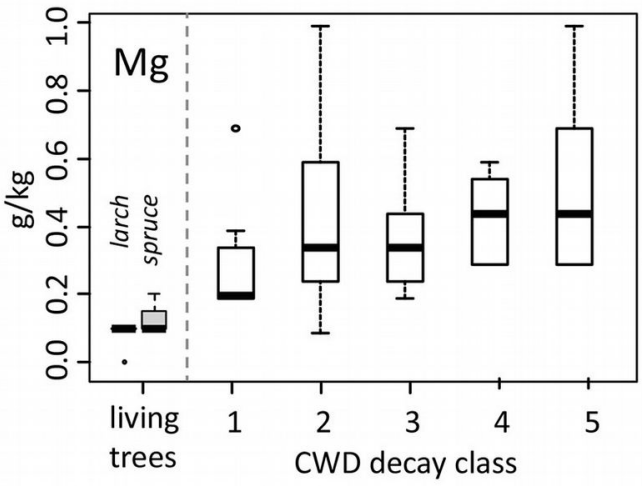

$\mathbf{F}$

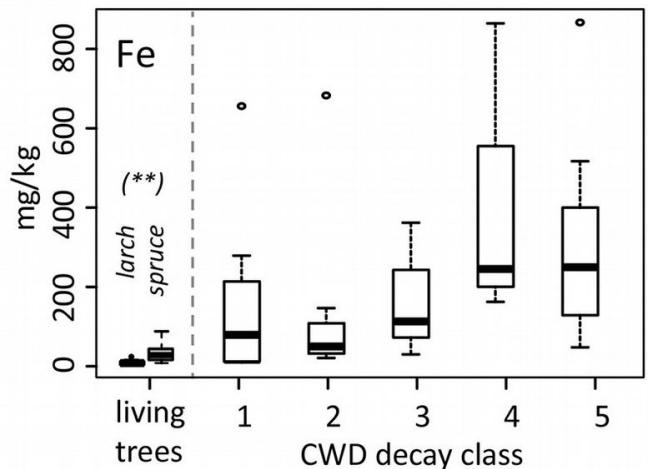

Fig. 3 - Elemental concentrations in the living trees and deadwood. Differences between the two types of living trees (European larch and Norway spruce) are indicated as follows: $\left(^{*}\right) P<0.05 ;(* *)$ : $P<0.01 ;(* * *): P<0.001$. With respect to CWD, no distinction between spruce and larch is made and the dataset is treated as one entity (see text for explanation).

\section{Living trees:}

European larch (on the left) $\square$ Norway spruce (on the right)

class, the differences became smaller or non-existent (Fig. 6).

When all decay classes pooled together are taken into account, however, the effect of site exposure and elevation on the cellulose content did not seem to be relevant $(P>0.05$ - Tab. 4). This is in contrast to the lignin content, which exhibited a highly significant difference $(P=0.007)$ between opposite aspects (Tab. 4). Lignin showed significantly lower concentrations particularly in the decay classes 1,2 and 3 at the north-facing sites $(22 \%, 25 \%, 30 \%$ at north-facing sites vs. $29 \%, 32 \%, 41 \%$ at southfacing sites).

No significant effect of elevation on lignin was detected. Carbon concentrations significantly varied (although the differences were small) with elevation (average values: $48 \%$ at $1200 \mathrm{~m}$ a.s.l., $45 \%$ at 1400 and 1600 $\mathrm{m}$ a.s.l., $46 \%$ at $2000 \mathrm{~m}$ a.s.l.), but site aspect had no effect. The carbon isotopic signature $\left(\delta^{13} \mathrm{C}\right)$ was the only parameter that was significantly influenced by both 
Fig. 4 - Water content (A) and wood density (B) given for the individual decay classes (spruce and larch is treated as one dataset; see text for explanation). Different letters indicate significant differences among groups tested using multiple comparison tests (non-parametric ANOVA, Kruskal-Wallis) with a significance level at $P<0.05$.

Fig. 5 - Correlation (Spearman's rank correlation coefficient) between the cellulose and lignin content in the deadwood.

\section{A}

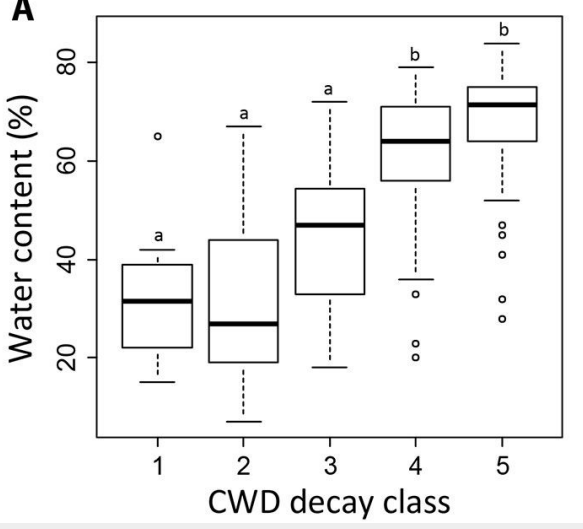

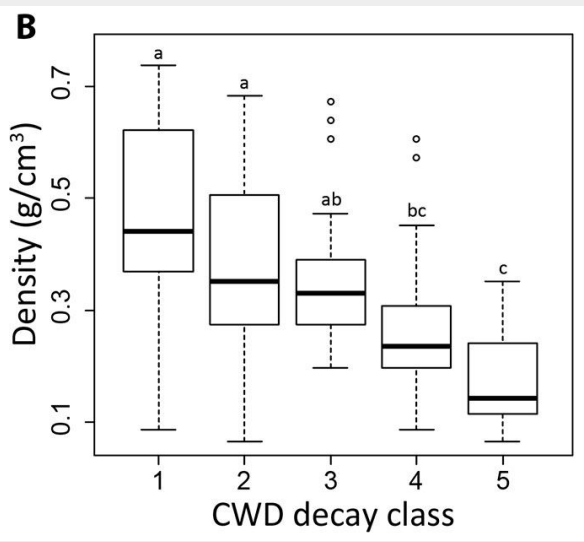

B

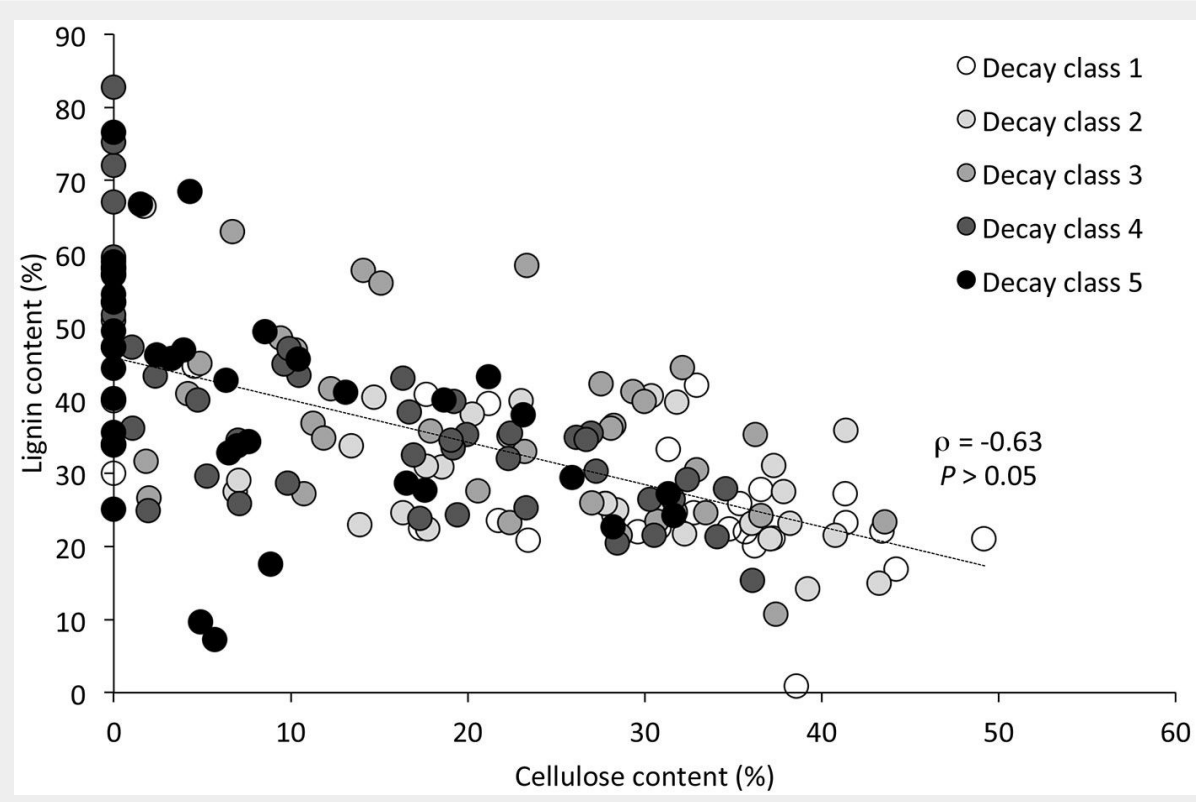

site elevation and aspect (Tab. 4). The $\delta^{13} \mathrm{C}$ isotopic ratio was less negative with increasing elevation up to $1600 \mathrm{~m}$ a.s.l., and again more negative at $2000 \mathrm{~m}$ a.s.l. (Fig. 7, left panel). The more negative value at $2000 \mathrm{~m}$ a.s.l. was probably caused not only by climate but more likely by the change from spruce to larch CWD. Moreover, CWD of the south-facing sites had, in general, a significantly $(P=0.004)$ less negative isotopic ratio compared to the north-facing sites (Fig. 7, right panel). Consequently, the $\delta^{13} \mathrm{C}$ isotopic ratio reflected the different climatic conditions to a certain extent. Elevation had a significant effect on the calcium concentration that decreased in the CWD along the altitudinal gradient from $4.5 \mathrm{~g} \mathrm{~kg}^{-1}$ at $1200 \mathrm{~m}$ to $1.2 \mathrm{~g} \mathrm{~kg}^{-1}$ at $2000 \mathrm{~m}$ a.s.l. (average values). Also the $\mathrm{K}$ concentrations were significantly lower at the uppermost site $\left(0.8 \mathrm{~g} \mathrm{~kg}^{-1}\right.$ at $1200 \mathrm{~m}$ a.s.l., vs. $0.3 \mathrm{~g} \mathrm{~kg}^{-1}$ at $2000 \mathrm{~m}$ a.s.l.). A similar significant trend with altitude was also detectable for phosphorous. No significant effect of the site aspect on nutrient concentrations was found.

\section{C-stocks in CWD}

The values of the CWD volume and related carbon stocks at the eight study

sites are reported in Tab. 5. The C-stocks were not uniform along the toposequences and varied between 3 and $17 \mathrm{Mg} \mathrm{ha}^{-1}$. Due to the low number of observations, no statistically robust trend as a function of $\mathrm{Mg} \mathrm{ha}^{-1}$ ).

Tab. 4 - Effect of the decay stage (decay-class), elevation and exposure on chemical and physical parameters. The Spearman's rank correlation coefficient $\rho$ was used for the comparison of chemical and physical wood parameters with the factors "Decay class" and "Elevation". Significant relationships with $p<0.05\left(^{*}\right), p<0.01\left(^{* *}\right)$ and $p<$ $0.001(* * *)$ are indicated. The Wilcoxon-Mann-Withney test was used (probability values $P$ are given) to derive wood parameters differences between north- and southfacing slopes (factor "exposure"). (1): $n=177 ;(2): n=40$.

\begin{tabular}{lccc}
\hline Parameter & Decay-class $(\rho)$ & Elevation $(\rho)$ & Exposure $(P)$ \\
\hline Water content ${ }^{(1)}$ & $0.72^{* * *}$ & -0.11 & 0.312 \\
Density $^{(1)}$ & $-0.62^{* * *}$ & $0.19^{*}$ & 0.919 \\
Cellulose $^{(1)}$ & $-0.55^{* * *}$ & 0.05 & 0.116 \\
Lignin $^{(1)}$ & $0.38^{* * *}$ & 0.01 & $0.007^{* *}$ \\
& & & (north: lower content) \\
$\mathrm{C}^{(1)}$ & -0.01 & -0.14 & 0.830 \\
$\mathrm{\delta}^{13} \mathrm{C}^{(1)}$ & -0.00 & $0.24^{* *}$ & $0.004^{* *}$ \\
& & & (north: more negative) \\
$\mathrm{K}^{(2)}$ & -0.08 & $-0.32^{*}$ & 0.369 \\
$\mathrm{Ca}^{(2)}$ & $0.41^{* *}$ & $-0.45^{* *}$ & 0.323 \\
$\mathrm{Mg}^{(2)}$ & $0.37^{*}$ & -0.24 & 0.069 \\
$\mathrm{P}^{(2)}$ & $0.58^{* * *}$ & $-0.34^{*}$ & 0.565 \\
$\mathrm{Fe}^{(2)}$ & $0.46^{* *}$ & -0.21 & 0.072 \\
$\mathrm{Mn}^{(2)}$ & 0.20 & -0.29 & 0.678 \\
$\mathrm{~N}^{(2)}$ & $0.66^{* * *}$ & -0.28 & 0.337 \\
\hline
\end{tabular}



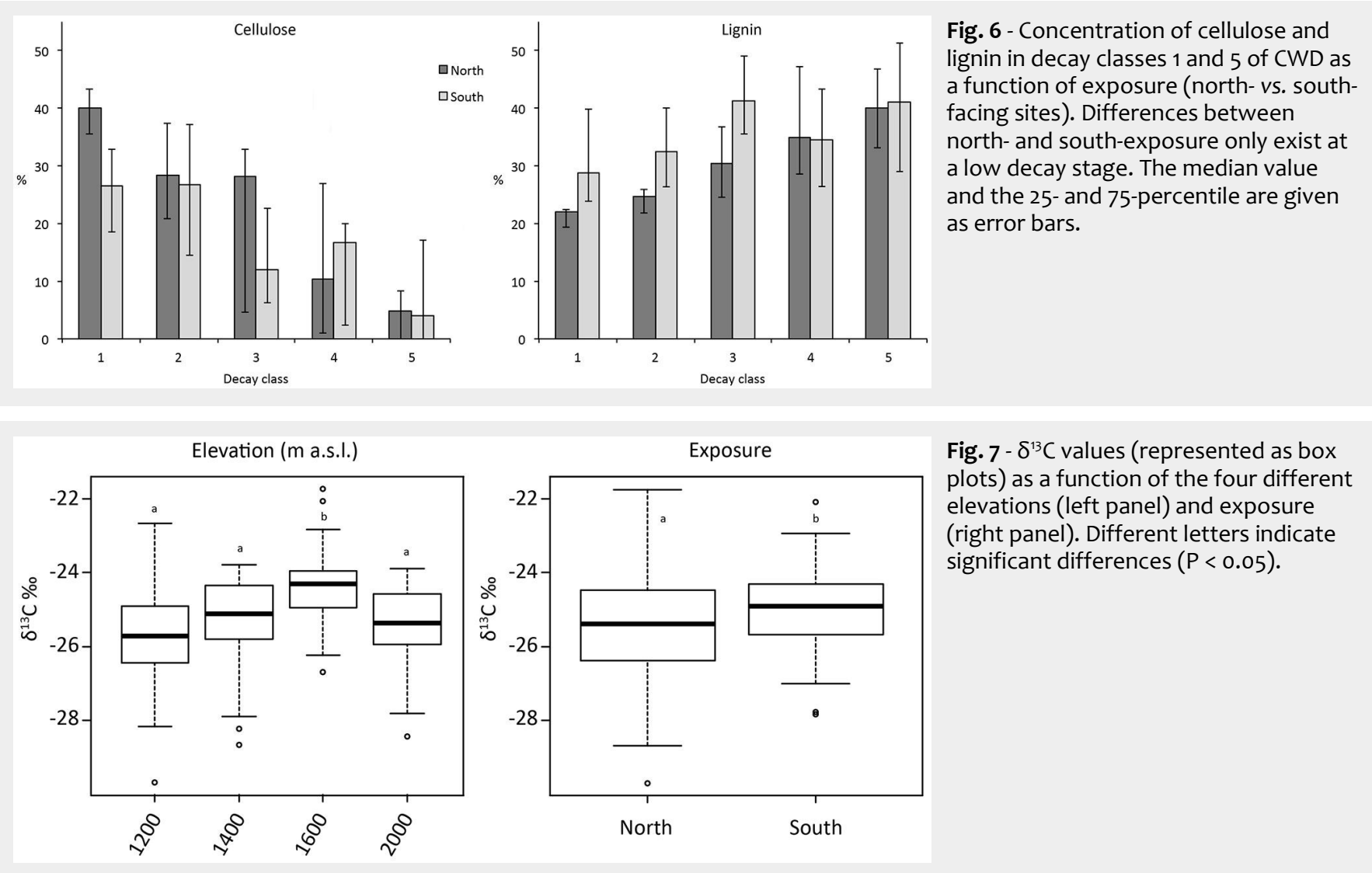

Fig. 7 - $\delta^{13} \mathrm{C}$ values (represented as box plots) as a function of the four different elevations (left panel) and exposure (right panel). Different letters indicate significant differences $(P<0.05)$.

Tab. 5 - Deadwood volume $\left(\mathrm{m}^{3} \mathrm{ha}^{-1}\right)$ and C stock (Mg ha $\left.{ }^{-1}\right)$ for each plot.

\begin{tabular}{lcc}
\hline Plot & $\begin{array}{c}\text { Volume } \\
\left(\mathrm{m}^{3} \mathrm{ha}^{-1}\right)\end{array}$ & $\begin{array}{c}\text { C stock } \\
\left(\mathrm{Mg} \mathrm{ha}^{-1}\right)\end{array}$ \\
\hline N01 & 78 & 17 \\
N02 & 45 & 9 \\
N03 & 55 & 10 \\
N04 & 18 & 3 \\
S06 & 16 & 3 \\
S07 & 52 & 14 \\
S08 & 70 & 10 \\
S09 & 22 & 6 \\
\hline
\end{tabular}

\section{Discussion}

Norway spruce and European larch characteristics

In spite of the complex experimental design (nested, unbalanced), with two different species (Norway spruce and European larch), we were able to define common patterns of CWD decomposition. Different authors investigated the role of species-specific traits in wood decomposition (Weedon et al. 2009). However, the two coniferous species under investigation which are commonly found in the Alps did not exhibit a species-specific behavior with respect to the physico-chemical characteristics of the decay classes. We were able to demonstrate that physico-chemical parameters undergo distinct changes at different decomposition stages (see below), and that they can be (but not always are) influenced by elevation and/or site aspect. Furthermore, some other CWD properties are clearly influenced by elevation and/or aspect, but do not vary along the decomposition process (such as $C$ and $\delta^{13} \mathrm{C}$ ).

\section{Physical-chemical parameters changing} with decomposition stage, but less strongly affected by elevation and aspect

The increasing water content and the decreasing density of CWD along the decomposition process can be explained by the gradual loss of wood structure. Water content of CWD is often reported to correlate negatively with wood density (Mackensen et al. 2003). Also Bütler et al. (2007) described a similar pattern. In contrast to our results, Pichler et al. (2012) found a Ushaped distribution of the water content values, with a tendency to drier conditions in class 2 and a distinct increase in moisture in class 3. In this study, the highest difference in water content between north- and south-facing sites was found in the decay class 5, when deadwood was in close contact to soil and partly mixed with it. For this reason, it can be assumed that site exposure drives changes in soil moisture regime (Egli et al. 2006), which are also reflected by the CWD water content. The measured nutrient concentrations in CWD fit well to those documented in the literature (Laiho $\&$ Prescott 2004, Palviainen et al. 2010). However, $\mathrm{P}$ concentrations at the investigated sites were slightly higher than those reported elsewhere (Bütler et al. 2007, Hellsten et al. 2013). Deadwood is in general a rather nutrient-poor substrate when compared to litter, leaves and needles
(Weis et al. 2009, Vestin et al. 2013). With increasing the decay stage, the elemental contents (nitrogen and phosphorus) usually increase. An increase in elemental contents in deadwood during decomposition has also been reported by Bütler et al. (2007), Palviainen et al. (2010) and Lombardi et al. (2013). These authors ascribe this phenomenon to the active nutrient transfer from the forest floor by mycelia cords of wood-decaying fungi (Harmon et al. 1986). Apart from this, an increase in nutrients is also due to a relative enrichment caused by organic matter decay (and thus loss in carbon and mass in general). By performing a mass balance calculation, an active nutrient transfer can be distinguished from a passive enrichment. For this purpose, a volume-based calculation was done using the following equation (eqn. 4):

$$
E F_{i}=\frac{C_{i} \cdot \rho_{i}}{C_{1} \cdot \rho_{1}}
$$

where $E F_{\mathrm{i}}$ is the the enrichment factor of the component of interest in the decay class $\mathrm{i}, C_{\mathrm{i}}$ is the concentration in the decay class $i, \rho_{\mathrm{i}}$ is the the density of CWD in the decay class $i, C_{1}$ is the concentration in the decay class 1 and $\rho_{1}$ is the the density of CWD in decay class 1. An EF value $<1$ indicates a depletion and a value $>1$ indicates an enrichment. This calculation showed that about $60-70 \%$ of the initial carbon (decay class 1) was lost during decay. The amount of phosphorus, however, remained more or less constant over all decay classes. Consequently, an active nutrient 
transfer during decay from the forest floor seems to be rather negligible. A moderately comparable situation for $\mathrm{P}$ was also measured in woody debris in the Mediterranean-type climate area in Australia (Brown et al. 1996) and CWD in the continental and cool climate area (Alban \& Pastor 1993). However, the amount of nitrogen increased (in the range of about +50 to $+100 \%$ ). Therefore, nitrogen was actively transferred into CWD - most likely due to fungi. Accumulation of nitrogen in CWD has also been observed in a similar range elsewhere for other tree species (Alban \& Pastor 1993, Brown et al. 1996, Hale \& Pastor 1998). According to Hale \& Pastor (1998), the level of rot prior to tree death may alter the patterns of nutrient flows in hollow logs compared to solid logs (hollow logs accumulate $\mathrm{N}$ more rapidly than do solid logs, but they begin to mineralize this pool earlier). This process seems to occur more frequently in deciduous stands than in coniferous forests. Nitrogen fixation may also occur in the logs but the rates usually seem to be too low to explain an accumulation of nutrient elements (Laiho \& Prescott 2004). As a consequence of $C$ losses and $\mathrm{N}$ inputs, the $\mathrm{C} / \mathrm{N}$ ratio of $\mathrm{CWD}$ decreases with increasing decay stage (Tab. 6 - Bütler et al. 2007). The relatively low $\mathrm{C} / \mathrm{N}$ ratio at $1400 \mathrm{~m}$ a.s.l. (south-facing slope) in decay class 1 might have been due to fungi that were already present in the wood samples and therefore gave rise to an elevated $\mathrm{N}$ concentration. The variability of the $\mathrm{C} / \mathrm{N}$ ratio is relatively high. High $\mathrm{C} / \mathrm{N}$ ratios are due to a low concentration of $\mathrm{N}$. With very low $\mathrm{N}$ contents the analytical precision may decrease, giving rise to an increased variability of the $\mathrm{C} / \mathrm{N}$ ratio.

The negative relationship of $\mathrm{Ca}, \mathrm{K}$ and $\mathrm{P}$ in CWD with altitude is probably related to the strongly leaching conditions at high altitudes due to cooler and wetter climate conditions. A similar effect could be observed in the same area for soils (Egli et al. 2006).

\section{Cellulose and lignin influenced by} decomposition pattern and partially by exposure

Cellulose was depleted with increasing decay class. Similar results were found for silver fir (Abies alba) and beech (Fagus sylvatica) in the Apennines (Lombardi et al. 2013) and for Norway spruce (Picea abies) in the Swiss Jura Mountains (Bütler et al. 2007), although in the latter study the trend was less obvious. In contrast to cellulose, the relative content of lignin increased. The significant negative correlation (Fig. 5) between cellulose and lignin can be explained by a preferential degradation of cellulose by brown rot fungi (Ganjegunte et al. 2004, Bütler et al. 2007, Lombardi et al. 2013). The lignin increase is caused by its relatively slower decomposition and therefore it becomes enriched in the remaining CWD.

Exposure had a significant effect on the
Tab. 6 - $\mathrm{C} / \mathrm{N}$ ratio in the decay classes 1 and 5 at four different elevations and as a function of the site aspect.

\begin{tabular}{lccc}
\hline \multirow{2}{*}{ Aspect } & $\begin{array}{c}\text { Elevation } \\
\text { (m a.s.l.) }\end{array}$ & $\begin{array}{c}\mathbf{1} \\
(\mathbf{C} / \mathbf{N})\end{array}$ & $\mathbf{5}$ \\
\cline { 3 - 4 } & & 313 & 144 \\
\hline North-facing sites & 1200 & 564 & 65 \\
& 1400 & 310 & 70 \\
& 1600 & 496 & 174 \\
\hline South-facing sites & 2000 & 450 & 92 \\
& 1200 & 82 & 109 \\
& 1400 & 223 & 118 \\
& 1600 & 376 & 215 \\
\hline
\end{tabular}

lignin content of CWD. Interestingly, differences between north-facing and southfacing sites were higher in class 1 , less pronounced in classes 2 and 3 and negligible in classes 4 and 5 (Fig. 6). As decomposition progresses, these differences tend to diminish. The differences at the beginning of the decay stage are difficult to explain, because they do not exist in the living trees. These differences probably depend more on site-specific properties such as moisture and temperature - particularly for the decay class 1 where CWD is often not in contact with the soil. According to Strukelj et al. (2013), logs become more similar to the forest floor with on-going decomposition.

Carbon and $\delta^{13} \mathrm{C}$ undifferentiated during decomposition, but sensitive to

elevation and exposure

Similarly to our finding, Ganjegunte et al. (2004), Bütler et al. (2007), Lombardi et al. (2013) and Strukelj et al. (2013) observed that the $C$ content did not change with decay class. However, Sakai et al. (2012) found that carbon concentration of CWD of Japanese conifers varied among the decay classes, but no consistent pattern was observed. Harmon et al. (2013) measured an increase in carbon from 48.3 to $52 \%$ with increasing decay classes. They explained this increase as being due to the longer residence time of wood pieces in the last decay classes and the prevalence of brown-rot fungi in gymnosperms (Gilbertson 1980). Furthermore, our measured $C$ values in the deadwood were slightly lower when compared to other investigations (Bütler et al. 2007). One of the most interesting findings is that the carbon isotopic signature $\left(\delta^{13} C\right)$ was not varying with decay classes, but was sensitive to site elevation and aspect. The variation of $\delta^{13} \mathrm{C}$ with altitude and exposure is not caused by differences in the ${ }^{13} \mathrm{C}$ content of the starting material. With respect to altitude, the signal in the living tree was opposite to that of the CWD: with increasing altitude, $\delta^{13} \mathrm{C}$ tended to more negative values (from about -24.6 to $-26.0 \%$ ). This trend most likely reflects air humidity and soil moisture conditions. Eilmann et al. (2010) showed that maximum $\delta^{13} \mathrm{C}$ values in tree rings were measured after the hottest and driest period of the year. Likely, the differences between north and south exposure in the CWD are to a certain degree due to the starting material. Although not significant, living trees showed a lesser difference between north and south-facing sites $\left(\delta^{13} \mathrm{C}\right.$ of $-25.3 \%$ at north-facing sites and $-24.9 \%$ at south-facing sites).

With increasing decay, a ${ }^{13} \mathrm{C}$ depletion should be the consequence when the relative proportion of lignin increases (Fernandez et al. 2003, Preston et al. 2006, Dümig et al. 2013) because the $\delta^{13} \mathrm{C}$ of lignin is known to be usually more negative (depleted in ${ }^{13} \mathrm{C}$ ) than cellulose. However, our data do not reflect such pattern. The presence of microbial-derived organic compounds can induce a ${ }^{13} \mathrm{C}$ enrichment (Dümig et al. 2013). Kohzu et al. (2005) even reported about a selective incorporation of $\mathrm{a}^{13} \mathrm{C}$ enriched fraction by fungi. The $\delta^{13} \mathrm{C}$ differences can also be due to a temperaturedependent shift in the active microbial community causing a shift in the carbon pool being mineralized (Andrews et al. 2000). The interpretation of the $\delta^{13} \mathrm{C}$ values is more challenging when the elevation trend is considered (Fig. 7, left panel). The trend of less-negative values with altitude (up to $1600 \mathrm{~m}$ a.s.l.) seems to reflect a climate signal: indeed, a cooler climate often leads to less negative $\delta^{13} \mathrm{C}$ values (Hikosaka et al. 2002). Ascher et al. (2012) detected distinct differences in the macro- and micro-organism composition in subalpine forest soils (in a similar area in Trentino) due to different thermal conditions. Species richness of microannelid assemblages was higher under warmer conditions (south exposure, lower altitude) and the vertical distribution of microannelids shifted along the gradient to lower temperatures from predominant occurrence in the mineral soil to exclusive occurrence in the organic layer. Microbial biomass (total phospholipid fatty acids, DNA yields) was higher at the cooler sites (Ascher et al. 2012). The $\delta^{13} \mathrm{C}$ signatures of the PLFA markers suggested a lower decomposition rate at the cooler sites, resulting in a lower respiratory loss and an accumulation of weakly decomposed organic material (Ascher et al. 2012). By determining microbial community composition, Djukic et al. (2013) demonstrated 
that environmental and site conditions may influence the decomposition process even more substantially than changes in substrate quality.

\section{Carbon stocks in CWD}

CWD in European natural forests is frequently in the range of $50-120 \mathrm{~m}^{3} \mathrm{ha}^{-1}$ (Bobiec et al. 2005) with values up to $160 \mathrm{~m}^{3}$ ha $^{-1}$ (Bobiec 2002). In our study area, the CWD volume was ranging between 16 and $78 \mathrm{~m}^{3} \mathrm{ha}^{-1}$, thus at the lower end of the above-mentioned range. The measured $C$ stocks in the CWD corresponded well to values reported in the literature for similar sites (Sandström et al. 2007). CWD is a nonnegligible $C$ reservoir in subalpine forests. However, the C-stocks in the soils are much more abundant - a fact that is well-known (Johnston et al. 2004). In the investigation area, $8-35 \mathrm{~kg} \mathrm{C} \mathrm{m}^{-2}$ is stored in the soils (Egli et al. 2006), whereas $0.3-1.7 \mathrm{~kg} \mathrm{C} \mathrm{m}^{-2}$ is found in the CWD. Consequently, only $5 \%$ of the amount of carbon found in soils is stored in the CWD.

\section{Conclusions}

The decomposition of coniferous wood in subalpine forests can be traced back very well by using the five decay-class system. Important wood physico-chemical parameters such as wood density, water content, lignin and cellulose concentration strongly correlate with the decay-classes. Not only major but also minor constituents showed a tight relationship to these classes. Among these components were N, Ca, Mg, $\mathrm{P}, \mathrm{Fe}$ and to a lower extent $\mathrm{Mn}$. In contrast, carbon concentrations and, interestingly, the $\delta^{13} \mathrm{C}$ ratio remained unaltered along the entire decomposition process.

Although wood chemistry for some compounds differed slightly between Norway spruce (Picea abies (L.) Karst) and European larch (Larix decidua Mill.), no significant chemical differences between these two species seem to exist any more during the whole decomposition process. Consequently, we have to reject our initial hypothesis that a different substrate should be traceable during CWD decomposition. It is interesting to note that these differences are zeroed already in decay class 1.

The site conditions also affected the chemical characteristics of CWD. Lignin varied with site exposure and the $\delta^{13} \mathrm{C}$ isotope ratio varied with both elevation and exposure. Consequently, climate and site specific conditions exerted a distinct influence on the decay mechanisms. A site- and climate-specific effect, could not be detected for nitrogen, but could be detected for phosphorous and other nutrients (such as (a and $\mathrm{K}$ ).

\section{Acknowledgements}

This study is part of the DecAlp DACH project no. 205321L_141186. We are indebted to Dr. Fabio Angeli of the Ufficio distrettuale forestale - Malé (Trento, Italy) and his team of foresters for their support in the field. We also thank Dr. Dolores Asensio for her help in performing elemental and isotopic analysis. We are grateful to two anonymous reviewers for their helpful comments on an earlier version of the manuscript.

\section{References}

Alban DH, Pastor J (1993). Decomposition of aspen, spruce, and pine boles on two sites in Minnesota. Canadian Journal of Forest Research 23: 1744-1749. - doi: 10.1139/×93-220

Andrews JA, Matamala R, Westover KM, Schlesinger WH (2000). Temperature effects on the diversity of soil heterotrophs and $\delta^{13} \mathrm{C}$ of soil-respired $\mathrm{CO}_{2}$. Soil Biology and Biochemistry 32 (5): 699-706. - doi: 10.1016/S0038-0717(99) 00206-0

Ascher J, Sartori G, Graefe U, Thornton B, Ceccherini MT, Pietramellara G, Egli M (2012). Are humus forms, mesofauna and microflora in subalpine forest soils sensitive to thermal conditions? Biology and Fertility of Soils 48 (6): 709-725. - doi: 10.1007/s00374-012-0670-9

Berg B, Erhagen B, Johansson M, Vesterdal L, Faituri M, Sanborn P, Nilsson M (2013). Manganese dynamics in decomposing needle and leaf litter - a synthesis. Canandian Journal of Forest Research 43 (12): 1127-1136. - doi: 10.1139/ cjfr-2013-0097

Bobiec A (2002). Living stands and deadwood in the Bialowieza forest: Suggestions for restoration management. Forest Ecology and Management 165: 125-140. - doi: 10.1016/S0378-1127(01) 00655-7

Bobiec A, Gutowski JM, Zub K, Pawlaczyk P, Laudenslayer WF (2005). The afterlife of a tree. WWF Poland, Hajnówka, Warszawa, Poland, pp. 251.

Boettger T, Haupt M, Knoller K, Weise SM, Waterhouse JS, Rinne KT, Loader NJ, Sonninen $\mathrm{E}$, Jungner $\mathrm{H}$, Masson-Delmotte $\mathrm{V}$, Stievenard $M$, Guillemin MT, Pierre $M$, Pazdur A, Leuenberger $M$, Filot $M$, Saurer $M$, Reynolds $C E$, Helle $\mathrm{G}$, Schleser GH (2007). Wood cellulose preparation method and mass spectrometric analysis of delta $\mathrm{C}-13$, delta $\mathrm{O}-18$, and nonexchangeable delta $\mathrm{H}-2$ values in cellulose, sugar and starch: an interlaboratory comparison. Analytical Chemistry 79 (12): 4603-4612. - doi: 10.1021/ac07000 23

Brown S, Mo J, McPherson JK, Bell DT (1996). Decomposition of woody debris in Western Australia forests. Canadian Journal of Forest Research 26: 954-966. - doi: 10.1139/×26-105

Brown S (2002). Measuring carbon in forests: current status and future challenges. Environmental Pollution 116 (3): 363-372. - doi: 10.1016/ S0269-7491(01)00212-3

Bütler R, Patty L, Le Bayon RC, Guenat C, Schlaepfe R (2007). Log decay of Picea abies in the Swiss Jura Mountains of Central Europe. Forest Ecology and Management 242 (2-3): 791799. - doi: 10.1016/j.foreco.2007.02.017

Castellani C (1972). Tavole stereometriche ed alsometriche costruite per $\mathrm{i}$ boschi italiani [Growth and yield tables of Italian forests]. Annali dell'Istituto Sperimentale per l'Assestamento Forestale e per l'Alpicoltura. Trento, Italy, vol. 2, pp. 20-21. [in Italian]

Cornelissen JHC, Sass-Klaassen U, Poorter L, Van
Geffen K, Van Logtestijn RSP, Van Hal J, Goudzwaard L, Sterck FJ, Klaassen RKWM, Freschet GT, Van Der Wal A, Eshuis H, Zuo J, De Boer W, Lamers T, Weemstra M, Cretin V, Martin R, Den Ouden J, Berg MP, Aerts R, Mohren $G M J$, Hefting MM (2012). Controls on coarse wood decay in temperate tree species: birth of the LOGLIFE experiment. Ambio 41: 231-245. doi: 10.1007/s13280-012-0304-3

Dence CW, Lin SY (1992). Introduction. In: "Methods in lignin chemistry" (Lin SY, Dence CW eds). Springer, Heidelberg, Germany, pp. 119.

Djukic I, Zehetner F, Watzinger A, Horacek $M$, Gerzabek MH (2013). In situ carbon turnover dynamics and the role of soil microorganisms therein: a climate warming study in an Alpine ecosystem. FEMS Microbiology Ecology 83 (1): 112-124. - doi: 10.1111/j.1574-6941.2012.01449.x Dümig A, Rumpel C, Dignac M, Kögel-Knabner I (2013). The role of lignin for the $\delta^{13} C$ signature of $\mathrm{C}_{4}$ grassland and $\mathrm{C}_{3}$ forest soils. Soil Biology and Biochemistry 57: 1-13. - doi: 10.1016/j.soilbio. 2012.06.018

Egli M, Mirabella A, Sartori G, Zanelli R, Bischof S (2006). Effect of north and south exposure on weathering rates and clay mineral formation in Alpine soils. Catena 67 (3): 155-174. - doi: 10.1016 li.catena.2006.02.010

Eilmann B, Buchmann N, Siegwolf R, Saurer M, Cherubini P, Rigling A (2010). Fast response of Scots pine to improved water availability reflected in tree-ring width and $\partial^{13} \mathrm{C}$. Plant, Cell and Environment 33: 1351-1360. - doi: 10.1111/j.13 65-3040.2010.02153.x

Fernandez I, Mahieu N, Cadisch G (2003). Carbon isotopic fractionation during decomposition of plant materials of different quality. Global Biogeochemistry Cycles 17 (3): 1075. - doi: 10.1029/ 2001GB001834

Ganjegunte GK, Condron LM, Clinton PW, Davis MR, Mahieu N (2004). Decomposition and nutrient release from radiata pine (Pinus radiata) coarse woody debris. Forest Ecology and $\mathrm{Ma}$ nagement 187 (2-3): 197-211. - doi: 10.1016/S037 8-1127(03)00332-3

Gilbertson RL (1980). Wood-rotting fungi of North America. Mycologia 72 (1): 1-49. - doi: 10.2307/3759417

Hale CM, Pastor J (1998). Nitrogen content, decay rates, and decompositional dynamics of hollow versus solid hardwood logs in hardwood forests of Minnesota, USA. Canadian Journal of Forest Research 28: 1276-1285. - doi: 10.1139/ x98-097

Harmon ME, Franklin JF, Swanson FJ, Sollins $\mathrm{P}$, Gregory SV, Lattin JD, Anderson NH, Cline SP, Aumen NG, Sedell JR, Lienkaemper GW, Cromack K, Cummins KW (1986). Ecology of coarse woody debris in temperate ecosystems. Advances in Ecological Research 15: 133-302. - doi: 10.1016/S0065-2504(08)60121-X

Harmon ME, Fasth B, Woodall CW, Sexton J (2013). Carbon concentration of standing and downed woody detritus: effects of tree taxa, decay class, position, and tissue type. Forest Ecology and Management 291: 259-267. - doi: 10.1016/j.foreco.2012.11.046

Hellsten S, Helmisaari H, Melin Y, Skovsgaard JP, Kaakinen S, Kukkola M, Saarsalmi A, Petersson $\mathrm{H}$, Akselsson C (2013). Nutrient concentration in 
stumps and coarse roots of Norway spruce, Scots pine and silver birch in Sweden, Finland and Denmark. Forest Ecology and Management 290: 40-48. - doi: 10.1016/j.foreco.2012.09. 017

Hikosaka K, Nagamatsu D, Ishii HS, Hirose T (2002). Photosynthesis-nitrogen relationships in species at different altitudes on Mount Kinabalu, Malaysia. Ecological Research 17: 305-313. - doi: 10.1046/j.1440-1703.2002.00490.x

Hunter ML (1990). Wildlife, forests and forestry: principles of managing forests for biological diversity. Englewood Cliffs, NJ, USA, pp. 370. [online] URL: http://www.cabdirect.org/abstrac ts/19910654124.html

IUSS Working Group WRB (2007). World reference base for soil resources ( $2^{\text {nd }}$ edn). World Soil Resources Reports No. 103, First update, FAO, Rome, Italy, pp. 116.

Jann B (2005). Einführung in die Statistik. 2. bearbeitete Auflage [Introduction to statistics]. Oldenburg Wissenschaftsverlag, München, Germany, pp. 210. [in German]

Johnston CA, Groffman P, Breshears DD, Cardon ZG, Currie W, Emanuel W, Gaudinski J, Jackson RB, Lajtha K, Nadelhoffer K, Nelson D, Post WM, Retallack G, Wielopolski L (2004). Carbon cycling in soil. Frontiers in Ecology and the Environment 2 (10): 522-528. - doi: 10.1890/15409295(2004)002[0522:CCIS]2.0.CO;2

Kohzu A, Miyajima T, Tateishi T, Watanabe T, Takahashi M, Wada E (2005). Dynamics of ${ }^{13} \mathrm{C}$ natural abundance in wood decomposing fungi and their ecophysiological implications. Soil Biology and Biochemistry 37 (9): 1598-1607. doi: 10.1016/j.soilbio.2005.01.021

Kueppers LM, Southon J, Baer P, Harte J (2004). Dead wood biomass and turnover time, measured by radiocarbon, along a subalpine elevation gradient. Oecologia 141 (4): 641-651. - doi: 10.1007/s00442-004-1689-x

Laiho R, Prescott CE (2004). Decay and nutrient dynamics of coarse woody debris in northern coniferous forests: a synthesis. Canadian Journal of Forest Research 34 (4): 763-777. - doi: 10.1139/Xo3-241

Lombardi F, Cherubini P, Tognetti R, Cocozza C, Lasserre B, Marchetti M (2013). Investigating biochemical processes to assess deadwood decay of beech and silver fir in Mediterranean mountain forests. Annals of Forest Science 70 (1): 101-111. - doi: 10.1007/s13595-012-0230-3

Mackensen J, Bauhus J, Webber E (2003). Decomposition rates of coarse woody debris - a review with particular emphasis on Australian tree species. Australian Journal of Botany 51 (1): 27-37. - doi: 10.1071/BT02014

Palviainen $M$, Finén $L$, Laiho $R$, Shorohova $E$,
Kapitsa E, Vanha-Majamaa I (2010). Phosphorus and base cation accumulation and release patterns in decomposing Scots pine, Norway spruce and silver birch stumps. Forest Ecology and Management 260 (9): 1478-1489. - doi: 10.1016/j. foreco.2010.07.046

Pan Y, Birdsey RA, Fang J, Houghton R, Kauppi PE, Kurz WA, Phillips OL, Shvidenko A, Lewis SL, Canadell JG, Ciais P, Jackson RB, Pacala SW, McGuire AD, Piao S, Rautiainen A, Sitch S, Hayes D (2011). A large and persistent carbon sink in the world's forests. Science 333 (6045): 988-993. - doi: 10.1126/science.1201609

Pichler V, Homolák M, Skierucha W, Pichlerová M, Ramírez D, Gregor J, Gialoviar P (2012). Variability of moisture in coarse woody debris from several ecologically important tree species of the Temperate Zone of Europe. Ecohydrology 5: 424-434. - doi: 10.1002/eco.235

Preston CM, Trofymow JA, Flanagan LB (2006). Decomposition, delta $\mathrm{C}-13$, and the "lignin paradox". Canadian Journal of Soil Science 86: 235245. - doi: 10.4141/S05-090

Risch CA, Jurgensen FM, Page-Dumroese DS, Schüt M (2013). Initial turnover rates of two standard wood substrates following land-use change in subalpine ecosystems in the Swiss Alps. Canadian Journal of Forest Research 43 (10): 901-910. - doi: 10.1139/cjfr-2013-0109

Rock J, Badeck FW, Harmon ME (2008). Estimating decomposition rate constants for European tree species from literature sources. European Journal of Forest Research 127: 301-313. doi: 10.1007/s10342-008-0206-x

Rondeux J, Sanchez C (2010). Review of indicators and field methods for monitoring biodiversity within national forest inventories. Core variable: deadwood. Environmental Monitoring Assessment 164: 617-630. - doi: 10.1007/s10661009-0917-6

Sakai Y, Ugawa S, Ishizuka S, Takahashi M, Takenaka C (2012). Wood density and carbon and nitrogen concentrations in deadwood of Chamaecyparis obtusa and Cryptomeria japonica. Soil Science and Plant Nutrition 58 (4): 526-537. - doi: 10.1080/00380768.2012.710526

Sandström F, Petersson H, Kruys N, Ståhl G (2007). Biomass conversion factors (density and carbon concentration) by decay classes for dead wood of Pinus sylvestris, Picea abies and Betula spp. in boreal forests of Sweden. Forest Ecology and Management 243 (1): 19-27. - doi: 10.1016/j.foreco.2007.01.081

Saunders MR, Fraver S, Wagner RG (2011). Nutrient concentration of down woody debris in mixedwood forests in central Maine, USA. Silva Fennica 45: 197-210. - doi: 10.14214/sf.112 tino - distribuzione spaziale delle principali variabili climatiche [The climate of Trentino - spatial distribution of the principal climatic variables]. Report 33, Centro di Ecologia Alpina Monte Bondone, Trento, Italy, pp. 20. [in Italian]

Seidl R, Schelhaas M, Rammer W, Verkerk PJ (2014). Increasing forest disturbances in Europe and their impact on carbon storage. Nature Climate Change Letters 4 (9): 806-810. - doi: 10.1038/NCLIMATE2318

Strukelj M, Brais S, Quideau SA, Angers VA, Kebli H, Drapeau P, Oh S (2013). Chemical transformations in downed logs and snags of mixed boreal species during decomposition. Canadian Journal of Forest Research 43 (9): 785-798. doi: 10.1139/cjfr-2013-0086

Talbot JM, Treseder KK (2012). Interactions among lignin, cellulose, and nitrogen drive litter chemistry-decay relationships. Ecology 93 (2): 345-354. - doi: 10.1890/11-0843.1

Teodosiu M, Bouriaud OB (2012). Deadwood specific density and its influential factors: a case study from a pure Norway spruce old-growth forest in the Eastern Carpathians. Forest Ecology and Management 283: 77-85. - doi: 10.1016/j. foreco.2012.06.050

Vestin JLK, Söderberg U, Bylund D, Nambu K, Hees PAW, Haslinger E, Ottner F, Lundström US (2013). The influence of alkaline and non-alkaline parent material on Norway spruce tree chemical composition and growth rate. Plant and Soil 370 (1-2): 103-113. - doi: 10.1007/s11104013-1615-2

Wang C, Bond-Lamberty B, Gower ST (2002). Environmental controls on carbon dioxide flux from black spruce coarse woody debris. Oecologia 132: 374-381. - doi: 10.1007/s00442-00 2-0987-4

Weedon JT, Cornwell WK, Cornelissen JHC, Zanne AE, Wirth C, Coomes DA (2009). Global meta-analysis of wood decomposition rates: a role for trait variation among tree species? Ecology Letters 12: 45-56. - doi: 10.1111/j.1461-02 48.2008.01259.x

Weis W, Gruber A, Huber C, Göttlein A (2009). Element concentrations and storage in the aboveground biomass of limed and unlimed Norway spruce trees at Höglwald. European Journal of Forest Research 128 (5): 437-445. doi: 10.1007/s10342-009-0291-5

Zhou L, Dai L, Gu H, Zhong L (2007). Review on the decomposition and influence of coarse woody debris in forest ecosystem. Journal of Forest Research 18: 48-54. - doi: 10.1007/s11676007-0009-9 